\title{
The effect of volume fraction on the fatigue strength of unsaturated polyester / glass fiber composite
}

\author{
Sundus A. Razzak \\ Department of Physics, College of Education for pure science, AL - Anbar University \\ E-mail: sundus_alzuhairi@yahoo.com
}

\begin{abstract} unsaturated polyester as a matrix reinforced with glass fiber type (E- fatigue strength, glass) with two different volume fraction $20 \% \& 40 \%$. Fatigue tests showed that the number of fatigue cycles to failure limit for samples reinforced with uniform (woven Roving 0-90 ${ }^{\circ}$ ) E-glass fiber and random (continuous fibers) with volume fraction $40 \%$ more than that for the same samples with volume fraction $20 \%$. Also the fatigue results showed that the uniform samples failed with fatigue cycles more than that of random.
\end{abstract}

In this work polymeric composites were done from volumefraction, unsaturated polyester / glass fiber composite.

Key words

\section{Article info.}

Received: Nov. 2012

Accepted: Jun. 2013

Published: Dec. 2013

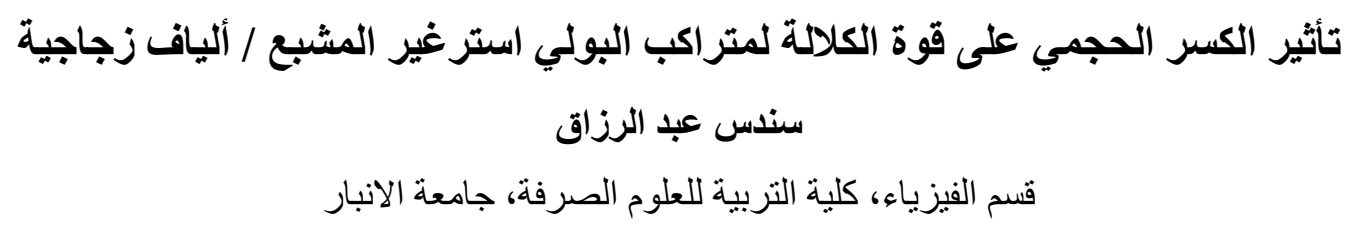

الخلاصة

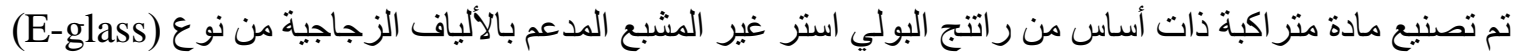

المنتظمة (90 - 0 0) و العشو ائية بكسرين حجمين (40\% , 20\%)، وتعريضها لفحص الكلال. لقد تم من خلال النتائج العملية ان عدد دورات الكلال لحد الفشل للعينات المنتظمة والعشئ العشائية عند كسر حجمي

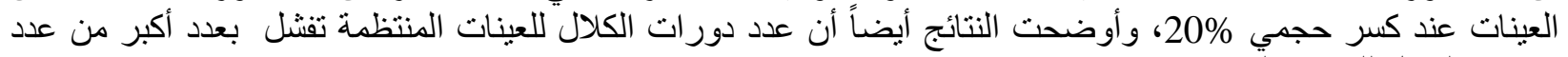
دورات الكلال للعينات العشو ائية.

\section{Introduction}

A composite may be defined as any multiple phase material that exhibits a significant proportion of the properties of both the constituent material, a judicious combination of properties[1].

The properties that can be improved by forming a composite material include high strength, weight, wear resistance, corrosion resistance, stiffness, fatigue life and thermal conductivity [2].
The term "polyester" resin is applied to the condensation reaction products of decides and dials (glycols). There are therefore, strictly alternating polymers of the type shown below[3]:

$\mathrm{A}-\mathrm{B}-\mathrm{A}-\mathrm{B}-\mathrm{A}-\mathrm{B}$

Unsaturated polyesters resins have excellent mechanical and chemical properties, good chemical and weather resistance, good electric, resistance to light, low cost [4]. 
Glass fiber reinforced polyester composites are used extensively in building and construction, transportation, electric industries and in domestic application [5].

Fatigue is the failure or decay of mechanical properties after repeated application of cyclic stress [6, 7]. Fatigue life is defined as the total number of stress cycles to cause failure at limit stress level[8]. The fatigue properties of composite material depend on factors as the interaction between the mechanical properties of the matrix and the reinforcement, the strength of the bond between the two, the volume or weight fraction of type of loading, the loading frequency and the temperature [9]. There are five major damage mechanisms matrix cracking, fiber breaking, crack coupling, delaminating beginning and delaminating growth [10].

Freire [11] investigated the damage mechanism and fracture prevention in Eglass polyester resin composites, his woke was limited to bidirectional and stacked bidirectional woven fabric textile. Husain[12] studied composite materials formulated by stacking four layers of fiber glass indifferent angle orientations immersed in polyester resin. These were texted under dynamic load in fully reversible tension-compression tests as fatigue testing. Hayder [13] studied experimental and theoretical investigation into some mechanical properties of glass polyester composite under static and dynamic loads. Hind [14] studied fatigue properties for polyester and epoxy resins reinforced with glass fiber.

\section{Experimental}

\section{Material used}

1. Unsaturated polyester(Siropol 8341) manufactured by Saudi Arabic Co. as a matrix material which solidified by addition its hardener (mekp) methyl / Ethy / Kenton peroxide with ratio $2 \mathrm{gm}$ to $100 \mathrm{gm}$ from unsaturated polyester at room temp. Table 1 showed the properties of unsaturated polyester.

2. Glass fiber type (E-glass) as a reinforced material with density $2-58 \mathrm{gm} / \mathrm{cm}^{3}$.

\section{Sample preparation}

Hand Lay-up produced was use to preparation the sample, because this way is easy, simple and cheap. This method includes:

1. Cutting up many laminates of fiber glass type (E-glass) random and woven roving with dimensions $(20 \times 20) \mathrm{cm}$.

2. Weigth the glass fibers by sensitive balance (0.0001 gm).

3 . The weight and volume of matrix including UP and hardner were known after knowing the weight and volume of fiber galss from the relation of volume fraction of fiber glass as follow:

$\phi_{f}=\frac{V_{f}}{\left(V_{f}+V_{m}\right)}=\frac{V_{f}}{V_{c}}$

where $\phi_{f}=$ the volume fraction of glass fiber

$\mathbf{V}_{\mathbf{m}}=$ volume of matrix ( polyester and hardener)

$\mathbf{V}_{\mathbf{f}}=$ volume of fiber

$\mathbf{V}_{\mathbf{c}}=$ volume composite matrix

$$
\mathbf{V}_{\mathbf{c}}=\mathbf{V}_{\mathbf{f}}+\mathbf{V}_{\mathbf{m}}
$$

4. Mixing the Unsaturated polyester and hardener very well to get homogeneity.

5. Pour some resin on the glass slate which covered with wax. Then put fiber sheet on the resin. After that putting some resin on the surface of fiber glass to cover it very well. The second glass fiber sheet put on the first one loading with suitable load.

6. After (24) hours the sample removed from glass slates and cured in dry oven (6h with $60^{\circ}$ ).

7. Cutting up the samples as in Table 2 with length $(100 \mathrm{~mm})$ and width $(10 \mathrm{~mm})$ for 
all samples, the thickness depends on the number of layers in the sample.

8. Make a hole in each sample with diameter $(4 \mathrm{~mm})$ at one edge with distance $(3 \mathrm{~mm})$ from the ribs, to connect the sample to device for the purpose of tests Fig. 1.

Table 1 : The physical properties of unsaturated polyester resins (UPE).

\begin{tabular}{|c|c|c|c|c|}
\hline \multirow{4}{*}{ UPE } & $\begin{array}{c}\text { dentsity } \rho \\
\left(\mathrm{g} / \mathrm{cm}^{3}\right)\end{array}$ & $\begin{array}{c}\text { Young } \\
\text { modulus } \\
\mathrm{E}(\mathrm{MPa})\end{array}$ & $\begin{array}{c}\text { Tensile } \\
\text { strength } \\
\sigma(\mathrm{MPa})\end{array}$ & $\begin{array}{c}\text { Thermal } \\
\text { conductivity } \\
\mathrm{K}\left(\frac{W}{M . K}\right)\end{array}$ \\
\cline { 2 - 5 } & $1.2-1.5$ & $2000-4500$ & $40-90$ & 0.2 \\
\hline
\end{tabular}

Table 2 : The type and number of reinforcing Layers of samples for unsaturated polyester/fiber glass composite.

\begin{tabular}{|c|c|c|c|c|}
\hline No. of samples & $\begin{array}{c}\text { Type of } \\
\text { samples }\end{array}$ & $\begin{array}{c}\text { Thickness } \\
(\mathrm{t}) \mathrm{mm}\end{array}$ & $\begin{array}{c}\text { Length } \\
\mathrm{L}(\mathrm{mm})\end{array}$ & $\begin{array}{c}\text { Width } \\
\mathrm{d}(\mathrm{mm})\end{array}$ \\
\hline M 1 & Pure & 1.25 & 100 & 10 \\
\hline M 2 & $\begin{array}{c}\text { UPE + 1 Un } \\
\text { G.f }\end{array}$ & 1.44 & 100 & 10 \\
\hline M 3 & $\begin{array}{c}\text { UPE + 2 Un } \\
\text { G.f }\end{array}$ & 1.61 & 100 & 10 \\
\hline M 4 & $\begin{array}{c}\text { UPE + Ra } \\
\text { G.f }\end{array}$ & 1.39 & 100 & 10 \\
\hline M5 & $\begin{array}{c}\text { UPE + 2 Ra } \\
\text { G.f }\end{array}$ & 1.57 & 100 & \\
\hline
\end{tabular}

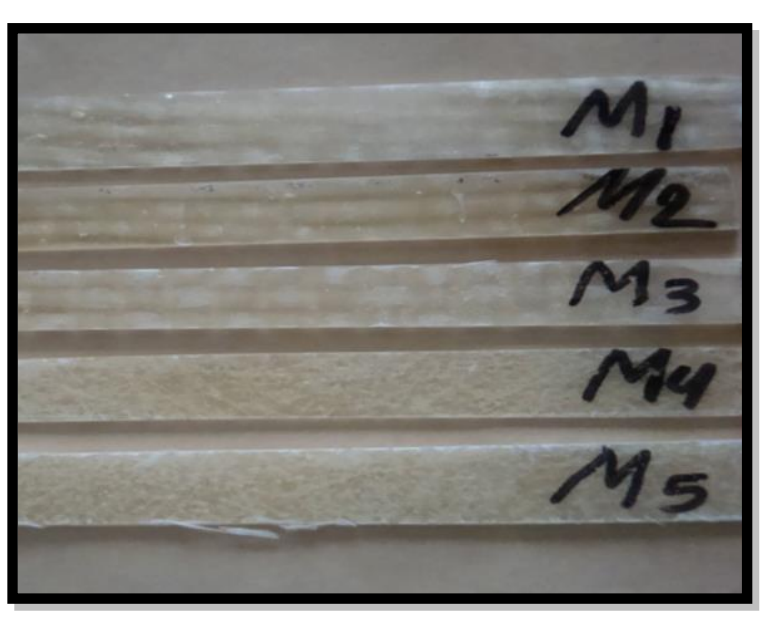

Fig .1: Prepared samples

\section{Instrumentations used}

\subsection{Alterbending Bending fatigue machine}

In this work we used the alternating bending fatigue machine which manufactured by Hi-tech British company (Fig. 2) to test the fatigue performance for all samples. by applying alternating or fluctuating bending to a cantilever strip or material.

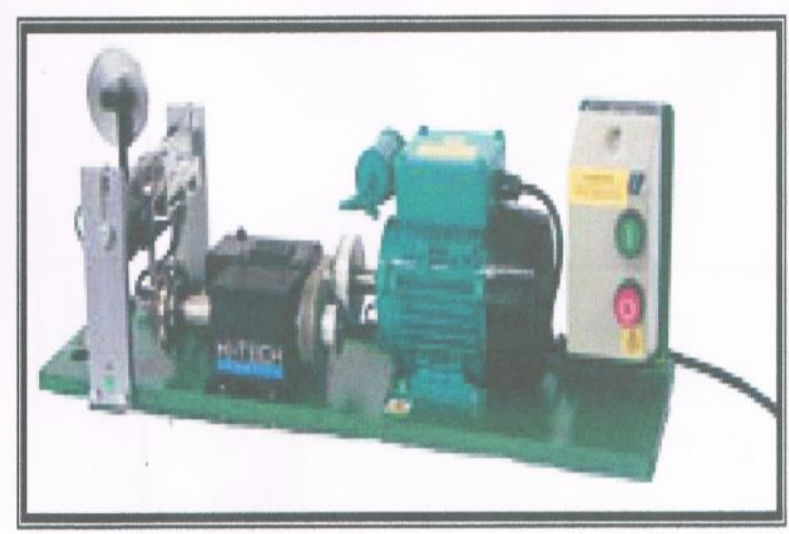

Fig .2 alternating bending fatigue machine 


\section{Results and Discussion}

Fatigue tests were done for samples of pure unsaturated polyester and for reinforced samples. The results for volume fraction $20 \%$ and $40 \%$ for uniform and random fibers distribution showed in Tables 3 and 4 respectively. Table 3 , shows that the pure sample of (UP) failed with fatigue cycles (5820) at load (4.5) N and deflection (5)mm. These cycles are less than that for reinforced samples, because (UP) have fast solidification after curing [15].

Table (3): The load, deflection and the number of cycles for unsaturated polyester samples (un Reinforcing and reinforcing with glass fiber at volume fraction $20 \%$.

\begin{tabular}{|c|c|c|c|c|}
\hline Sample No. & Type & $\begin{array}{c}\text { Load P } \\
(\mathrm{N})\end{array}$ & $\begin{array}{c}\text { Deflection } \delta \\
(\mathrm{mm})\end{array}$ & $\begin{array}{c}\text { No. of cycles } \\
\text { N }\end{array}$ \\
\hline M 1 & Pure & 4.5 & 5 & 5820 \\
\hline M 2 & $\begin{array}{c}\text { UPE + 1 Un } \\
\text { G.f }\end{array}$ & 6 & 18 & 1107580 \\
\hline M 3 & $\begin{array}{c}\text { UPE + 2 Un } \\
\text { G.f }\end{array}$ & 12 & 10 & 921044 \\
\hline M 4 & $\begin{array}{c}\text { UPE + Ra } \\
\text { G.f }\end{array}$ & 5.5 & 18 & $1 \times 10^{6}$ \\
\hline M 5 & $\begin{array}{c}\text { UPE + Ra } \\
\text { G.f }\end{array}$ & 11.0 & 10 & 823142 \\
\hline
\end{tabular}

Table (4) : The load, deflection and the number of cycles for unsaturated polyester samples (un Reinforcing and reinforcing with glass fiber at volume fraction $40 \%$.

\begin{tabular}{|c|c|c|c|c|}
\hline Sample No. & Type & $\begin{array}{c}\text { Load P } \\
(\mathrm{N})\end{array}$ & $\begin{array}{c}\text { Deflection } \delta \\
(\mathrm{mm})\end{array}$ & $\begin{array}{c}\text { No. of cycles } \\
\text { N }\end{array}$ \\
\hline M 1 & Pure & 4.5 & 5 & 5820 \\
\hline M 2 & $\begin{array}{c}\text { UPE + 1 Un } \\
\text { G.f }\end{array}$ & 7 & 18 & 1634144 \\
\hline M 3 & $\begin{array}{c}\text { UPE + 2 Un } \\
\text { G.f }\end{array}$ & 13 & 10 & 1131608 \\
\hline M 5 & $\begin{array}{c}\text { UPE + 1 Ra } \\
\text { G.f }\end{array}$ & 6.5 & 18 & 1485000 \\
\hline GPE + Ra & 12 & 10 & 901202 \\
\hline
\end{tabular}

Fig.3 shows that the samples reinforced with one layer of uniform glass fiber at volume fraction $20 \%$ failed with fatigue cycles (1107580) at load $6 \mathrm{~N}$ and deflection $18 \mathrm{~mm}$, when we compared this sample with the same sample at volume fraction $40 \%$, we found it failed with fatigue cycles(1634144) at load $7 \mathrm{~N}$ and def $18 \mathrm{~mm}$. This belongs to the reason that the tensile strength of the composite sample increased with increasing volume fraction[16].

Fig.3 showed the samples reinforced with two layer of uniform glass fiber at volume fraction $20 \%$ failed with fatigue cycles (921044) at load $12 \mathrm{~N}$ and def. $10 \mathrm{~mm}$, while this sample at volume fraction $40 \%$ failed with fatigue cycles (1131608) at load $13 \mathrm{~N}$ and deflection $10 \mathrm{~mm}$ for the same above reasons. 
Fig.4 shows the results of pure samples and reinforcing samples with random glass fiber. We noticed from the Fig.4 that the samples reinforced with one layer of random glass fiber with volume fraction $20 \%$ failed with fatigue cycles $\left(1 \times 10^{6}\right)$ at load $5.5 \mathrm{~N}$ and def. $18 \mathrm{~mm}$, but when we compared this sample with the same sample at volume fraction $(40 \%)$, we found it failed with fatigue cycles (1485000) at load $6.5 \mathrm{~N}$ and def. $18 \mathrm{~mm}$, Also the same results for two layers.

By comparing Fig.3 and 4, we noticed that the fatigue cycles decrease with increasing the number of reinforcing layers for all samples (random or uniform), also fatigue cycles at volume fraction $20 \%$ less than that at volume fraction $40 \%$.

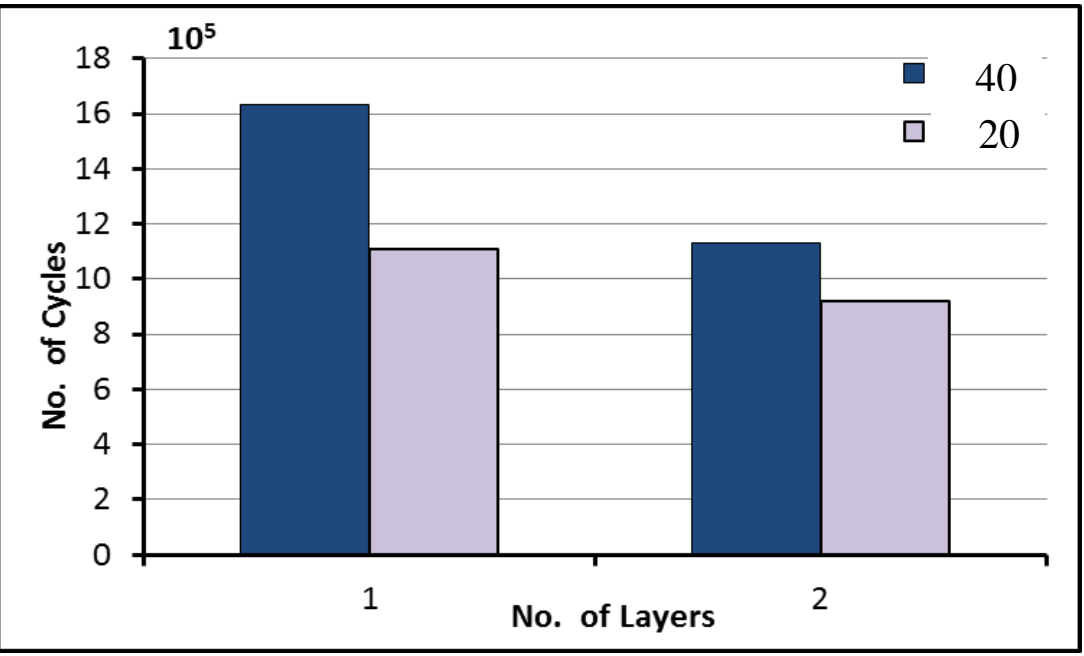

Fig.3: The relation between fatigue cycle and number of layer for uniform glass fiber at volume fractions $20 \%$ and $40 \%$.

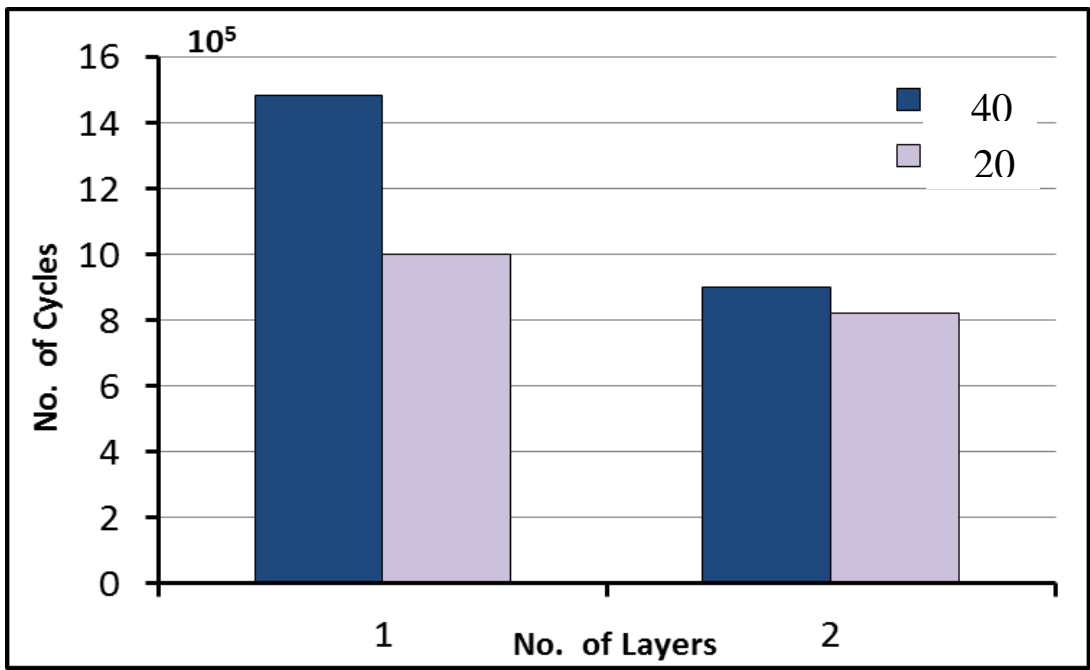

Fig.4: The relation between fatigue cycle and number of layer for random glass fiber at volume fractions $20 \%$ and $40 \%$. 


\section{Conclusions}

1. All samples with volume fraction $40 \%$ have fatigue strength more than that for samples with volume fraction $20 \%$.

2. Fatigue cycles to failure decreases with increasing the number of reinforcing layer.

\section{References}

[1] R.Harry Allcock, Fied like, W. James, E., "Contem porary chemistry", third Edition, printed UN United States of America, 2003.

[2] Asmmaa Shawky, "Study of the effect of additives on some mechanical and thermal properties for Epoxy Resin", Ph.D., Thesis, University of Baghdad, College of Science, 2007.

[3] F. R. Jones, "Handbook of polymer fiber composites", Longman group, U.K. Limited, 1994.

[4] P. K. Mallick, "Fiber reinforced composites materials, Manufacturing and Design", Taylor and Francis Group, LIC, United States of America, 2008.

[5] S. Kumar M, Neeti Sharma and B. C. Ray, Journal of Reinforced Plastics and Composites, 27( 2008) 1-17.

[6] N.G. Megrum, "Principle of polymer Engineering", Oxford Science publication, 1997.

[7] I.M. Ward, "Mechanical properties of Solid polymers", John Wiley and Sons LTD, London, 1993.

[8] William D. Callister, Jr. "Material Science and Engineering, An Introduction", John Wiley Sons, Inc, 2007.
[9] Mohammad Hussein, "Fatigue Behavior of Carbon Fiber Reinforced Epoxy and unsaturated polyester composites", M.Sc. Thesis, Baghdad University, College of Science, 2009.

[10] E.J.Barbero, "Introduction to composite to Material Design", Materials Science and Engineering series, $1^{\text {st }}$ Edition, Taylor and francis, Inc, 1998.

[11] R.C. Freire, and E.F. Aquino, Material Science Research, 8, 1 (2005) 45-49.

[12] H.M. Hosain, "Experimental into some mechanical properties of glass polyester composite under static and dynamic Loads", M.Sc. Thesis, University of Technology, Iraq, 2007.

[13] Muhannad Z. Khelifa and Hayder Moasa, Eng. and Technology, 26, 10, (2008)1210-1224.

[14] Hind Salah Hassan, "Study of the effect water absorption on fatigue property for polymer Reinforced with Glass fiber", M.Sc. Thesis, University of Al-Anbar, College of Education for Pure Science, 2012.

[15]R.A.Nseif, "Improve the material properties of composite unsaturated polyester resins developed by adding a rubber phase", M.Sc. Thesis, Applied Sciences Department, University of Technology, 2006.

[16]Kh. Th. Hassan, "The effect of the volumetric fraction of fibers on the mechanical and thermal properties of a composite and hybrid material ", M.Sc. Thesis, Applied Sciences Department, University of Technology, 2000. 